Supporting Information

Benzofuran-based carboxylic acids as carbonic anhydrase inhibitors and antiproliferative agents against breast cancer

Wagdy M. Eldehna, Alessio Nocentini, Zainab M. Elsayed, Tarfah Al-Warhi, Nada Aljaeed, Ohoud J. Alotaibi, Mohammad M. Al-Sanea, Hatem A. Abdel-Aziz, Claudiu T. Supuran 


\section{Tables of Contents}

1. Synthesis of Target Benzofuran-based Carboxylic Acids 9a-f and 3-5 11a,b

2. Carbonic Anhydrase Inhibition Assay 6

3. Anti-proliferative Activity Against Breast Cancer Cell Lines 7

4. Cell Cycle Analysis $\quad 8$

5. AnnexinV-FITC/PI Apoptosis Assay 8

6. References 9

7. NMR Spectra 10-23 


\section{Synthesis of Target Benzofuran-based Carboxylic Acids 9a-f and 11a,b}

\section{General Procedure}

Infrared (IR) Spectra are obtained by the use of Schimadzu FT-IR 8400S spectrophotometer as $\mathrm{KBr}$ disks and expressed in wave number $\left(\mathrm{cm}^{-1}\right)$. The NMR spectra were recorded on Bruker 400 (400/100 MHz for ${ }^{1} \mathrm{H}$ and ${ }^{13} \mathrm{C}$ NMR), in deuterated dimethylsulfoxide (DMSO- $d_{6}$ ). Chemical shifts $(\delta)$ are referenced to tetramethylsilane (TMS) as an internal standard and were reported as follows: multiplicity $(\mathrm{b}=$ broad, $\mathrm{s}=$ singlet, $\mathrm{d}=$ doublet, $\mathrm{t}=$ triplet, $\mathrm{m}=$ multiplet $)$.

\section{Synthesis of benzofuran-2-carbohydrazides intermediates $5 \mathrm{a}, \mathrm{b}$}

To a stirred suspension of ethyl benzofuran-2-carboxylates $\mathbf{4 a}, \mathbf{b}(0.01 \mathrm{~mol})$ in ethyl alcohol $(15 \mathrm{~mL})$, an excess $(2.5 \mathrm{~mL})$ of $99 \%$ hydrazine hydrate was added portion-wise. Then the reaction mixture was allowed to stir under reflux for $4 \mathrm{hrs}$. The obtained residue was filtered, washed several times with water and petroleum ether, dried and recrystallized from isopropyl alcohol to afford the corresponding intermediates benzofuran-2-carbohydrazides 5a, b in 79\% and $84 \%$ yield, respectively. Both spectral data and physical properties for hydrazides $\mathbf{4 a}, \mathbf{b}$ are analogous with those reported previously $[1,2]$.

General procedures for preparation of target benzofuran-based carboxylic acids 9a-f and $11 \mathbf{a}, \mathbf{b}$.

To a solution of benzofuran-2-carbohydrazides $\mathbf{5 a}$ and $\mathbf{5 b}(0.01 \mathrm{~mol})$ in acetic acid (15 $\mathrm{mL})$ in an ice bath, sodium nitrite $(1 \mathrm{~g}, 0.014 \mathrm{~mol})$ was added in a portion-wise manner, then the mixture was stirred for $1 \mathrm{hr}$. Thereafter the stirring was continued for another $2 \mathrm{hrs}$ at r.t. The obtained precipitate, upon filtration, was washed with water several times then dried to furnish benzofuran-2-carbonyl azides $\mathbf{6 a}, \mathbf{b}$, that subsequently used for the next reaction without more purification. After their drying, benzofuran-2-carbonyl azides 6a,b was stirred under reflux temperature for $1 \mathrm{hr}$ in dry xylene before addition of aminobenzoic acids 8a-c or paraaminohippuric acid 10. The resulting mixture was allowed to reflux for $5 \mathrm{hrs}$ then the formed solid, after cooling to r.t., was filtered, washed several times with cold water and petroleum ether, dried and recrystallized from acetonitrile affording the target benzofuran-based carboxylic acids $9 \mathbf{a}-\mathbf{f}$ and $\mathbf{1 1 a}, \mathbf{b}$, respectively.

\section{2-(3-(3-Methylbenzofuran-2-yl)ureido)benzoic acid (9a)}


White powder m.p. 221-222 ${ }^{\circ} \mathrm{C}$; (yield 83\%), IR: 3276, 3087, 1678 and 1643; ${ }^{1} \mathrm{H}$ NMR $\delta p p m$ : $2.14\left(\mathrm{~s}, 3 \mathrm{H}, \mathrm{CH}_{3}\right), 7.05$ (t, 1H, J = 7.6 Hz, Ar-H), 7.23-7.31 (m, 2H, Ar-H), 7.47 (d, 1H, J = 7.6 $\mathrm{Hz}, \mathrm{Ar}-\mathrm{H}), 7.55-7.58$ (m, 2H, Ar-H), 7.94 (d, 1H, J=8.0 Hz, Ar-H), 8.46 (d, 1H, J = 8.0 Hz, ArH), 9.75 (s, 1H, NH), 10.73 (s, 1H, NH); ${ }^{13} \mathrm{C}$ NMR $\delta p p m: ~ 8.06,107.00,111.13,115.69,119.69$, $119.78,121.78,122.91,124.53$, 130.02, 131.50, 134.51, 142.45, 144.11, 151.43, 153.10, 170.10; Anal. Calcd. for $\mathrm{C}_{17} \mathrm{H}_{14} \mathrm{~N}_{2} \mathrm{O}_{4}$ : C, 65.80; H, 4.55; N, 9.03; found C, 66.07; H, 4.51; N, 8.95.

\section{3-(3-(3-Methylbenzofuran-2-yl)ureido)benzoic acid (9b)}

White powder m.p. 270-272 ${ }^{\circ} \mathrm{C}$; (yield 72\%), IR: 3286, 3192, 3095 and 1686; ${ }^{1} \mathrm{H}$ NMR $\delta p p m$ : 2.12 (s, 3H, $\left.\mathrm{CH}_{3}\right), 7.22-7.30$ (m, 2H, Ar-H), 7.39-7.47 (m, 2H, Ar-H), 7.53 (d, 1H, J= 7.2 Hz, Ar-H), 7.58 (d, 1H, J=7.6 Hz, Ar-H), 7.70 (d, 1H, J=8.0 Hz, Ar-H), 8.14 (s, 1H, Ar-H), 8.82 (s, 1H, NH), 9.17 (s, $1 \mathrm{H}, \mathrm{NH}) ;{ }^{13} \mathrm{C}$ NMR $\delta$ ppm: 8.09, 106.21, 111.01, 119.55, 119.93, 122.85, 123.37, 123.58, 124.25, 129.42, 130.20, 131.76, 140.21, 144.53, 151.24, 153.16, 167.73; Anal.

Calcd. for $\mathrm{C}_{17} \mathrm{H}_{14} \mathrm{~N}_{2} \mathrm{O}_{4}$ : C, 65.80; H, 4.55; N, 9.03; found C, 65.62; H, 4.58; N, 9.12.

\section{4-(3-(3-Methylbenzofuran-2-yl)ureido)benzoic acid (9c)}

White powder m.p. $294-296{ }^{\circ} \mathrm{C}$; (yield 68\%), IR: 3275, 3181, 1673 and 1647; ${ }^{1} \mathrm{H}$ NMR $\delta p p m$ : 2.13 (s, 3H, $\left.\mathrm{CH}_{3}\right), 7.27-7.64$ (m, 6H, Ar-H), 7.91-7.93 (m, 2H, Ar-H), 8.89 (s, 1H, NH), 9.35 (s, $1 \mathrm{H}, \mathrm{NH}), 12.71$ (br. s, $1 \mathrm{H}, \mathrm{COOH}) ;{ }^{13} \mathrm{C} \mathrm{NMR} \delta$ ppm: 8.08, 106.23, 111.02, 118.18, 119.56, 122.88, 124.28, 124.85, 130.17, 130.94, 144.20, 144.36, 151.25, 152.88, 167.52; Anal. Calcd. for $\mathrm{C}_{17} \mathrm{H}_{14} \mathrm{~N}_{2} \mathrm{O}_{4}$ : C, 65.80; H, 4.55; N, 9.03; found $\mathrm{C}, 66.02 ; \mathrm{H}, 4.59 ; \mathrm{N}, 8.91$.

\section{2-(3-(5-Bromobenzofuran-2-yl)ureido)benzoic acid (9d)}

White powder m.p. $230-231{ }^{\circ} \mathrm{C}$; (yield 77\%), IR: 3290, 3208, 3110 and 1690; ${ }^{1} \mathrm{H}$ NMR $\delta p p m$ : $6.52(\mathrm{~s}, 1 \mathrm{H}, \mathrm{Ar}-\mathrm{H}), 7.08$ (t, 1H, J = 7.6 Hz, Ar-H), 7.25 (d, 1H, J = 8.8 Hz, Ar-H), 7.41 (d, 1H, $=8.8 \mathrm{~Hz}, \mathrm{Ar}-\mathrm{H}), 7.56(\mathrm{t}, 1 \mathrm{H}, J=8.0 \mathrm{~Hz}, \mathrm{Ar}-\mathrm{H}), 7.68(\mathrm{~s}, 1 \mathrm{H}, \mathrm{Ar}-\mathrm{H}), 7.97$ (d, 1H, J = 8.0 Hz, Ar$\mathrm{H}), 8.37(\mathrm{~d}, 1 \mathrm{H}, J=8.4 \mathrm{~Hz}, \mathrm{Ar}-\mathrm{H}), 10.59(\mathrm{~s}, 1 \mathrm{H}, \mathrm{NH}), 11.25(\mathrm{~s}, 1 \mathrm{H}, \mathrm{NH}) ;{ }^{13} \mathrm{C} \mathrm{NMR} \delta p p m$ : $87.33,112.39,115.90,116.52,120.42,122.17,122.28,124.71,131.51,132.48,134.31,141.75$, 148.53, 150.85, 152.04, 169.71; Anal. Calcd. for $\mathrm{C}_{16} \mathrm{H}_{11} \mathrm{BrN}_{2} \mathrm{O}_{4}: \mathrm{C}, 51.22 ; \mathrm{H}, 2.96$; N, 7.47; found C, 51.49; H, 3.00; N, 7.36.

\section{3-(3-(5-Bromobenzofuran-2-yl)ureido)benzoic acid (9e)}


White powder m.p. $244-246{ }^{\circ} \mathrm{C}$; (yield 80\%), IR: 3283, 3089, 1690 and $1659 ;{ }^{1} \mathrm{H}$ NMR $\delta$ ppm: $6.51(\mathrm{~s}, 1 \mathrm{H}, \mathrm{Ar}-\mathrm{H}), 7.25$ (d, 1H, J = 8.4 Hz, Ar-H), 7.41-7.46 (m, 2H, Ar-H), 7.61-7.69 (m, 3H, Ar-H), 8.16 (s, $1 \mathrm{H}, \mathrm{Ar}-\mathrm{H}), 9.13$ (s, $1 \mathrm{H}, \mathrm{NH}), 10.01$ (s, $1 \mathrm{H}, \mathrm{NH}),{ }^{13} \mathrm{C}$ NMR $\delta p p m: 86.60,112.38$, 115.95, 119.53, 119.71, 122.25, 123.19, 124.66, 129.44, 132.01, 132.56, 139.65, 148.44, 150.88, 151.80, 167.69; Anal. Calcd. for $\mathrm{C}_{16} \mathrm{H}_{11} \mathrm{BrN}_{2} \mathrm{O}_{4}$ : C, 51.22; H, 2.96; N, 7.47; found C, 51.35; H, $2.98 ; \mathrm{N}, 7.42$.

\section{4-(3-(5-Bromobenzofuran-2-yl)ureido)benzoic acid (9f)}

White powder m.p. $267-269^{\circ} \mathrm{C}$; (yield 85\%), IR: 3285, 3075 and 1663; ${ }^{1} \mathrm{H}$ NMR $\delta p p m$ : 6.52 (s, 1H, Ar-H), 7.26 (d, 1H, $J=8.4 \mathrm{~Hz}, \mathrm{Ar}-\mathrm{H}), 7.41$ (d, 1H, $J=8.4 \mathrm{~Hz}, \mathrm{Ar}-\mathrm{H}), 7.60$ (d, 2H, $J=8.0$ Hz, Ar-H), 7.68 (s, 1H, Ar-H), 7.90-7.92 (m, 2H, Ar-H), 9.24 (s, 1H, NH), 10.04 (s, 1H, NH); ${ }^{13}$ C NMR $\delta$ ppm: 87.02, 112.41, 115.97, 118.11, 122.33, 124.79, 124.94, 131.03, 132.48, 143.55, 148.46, 150.61, 151.53, 167.45; Anal. Calcd. for $\mathrm{C}_{16} \mathrm{H}_{11} \mathrm{BrN}_{2} \mathrm{O}_{4}$ : C, 51.22; H, 2.96; N, 7.47; found $\mathrm{C}, 51.03 ; \mathrm{H}, 2.93 ; \mathrm{N}, 7.55$.

\section{(4-(3-(3-Methylbenzofuran-2-yl)ureido)benzoyl)glycine (11a)}

White powder m.p. $240-242{ }^{\circ} \mathrm{C}$; (yield 78\%), IR: 3421, 3339, 3127, 1726, 1681 and $1653 ;{ }^{1} \mathrm{H}$ NMR $\delta$ ppm: 2.13 (s, 3H, CH 3 ), $3.92\left(\mathrm{~d}, 2 \mathrm{H}, J=5.6 \mathrm{~Hz}, \mathrm{NH}-\underline{\mathrm{C}}_{2}-\mathrm{COOH}\right), 7.23-7.30(\mathrm{~m}, 2 \mathrm{H}$, Ar-H), $7.46(\mathrm{~d}, 1 \mathrm{H}, J=7.6 \mathrm{~Hz}, \mathrm{Ar}-\mathrm{H}), 7.54(\mathrm{~d}, 1 \mathrm{H}, J=7.2 \mathrm{~Hz}, \mathrm{Ar}-\mathrm{H}), 7.57$ (d, 2H, $J=8.4 \mathrm{~Hz}$,

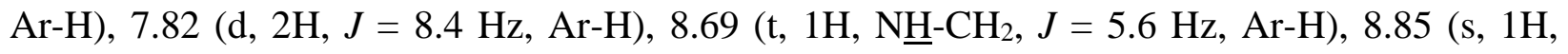

$\mathrm{NH}), 9.24$ (s, 1H, NH), 12.67 (br. s, $1 \mathrm{H}, \mathrm{COOH}$ ); ${ }^{13} \mathrm{C}$ NMR $\delta$ ppm: 13.53, 66.82, 106.17, 111.02, 118.14, 119.57, 122.88, 124.27, 127.80, 129.37, 130.18, 142.87, 144.44, 151.24, 152.95, 166.53, 171.94; Anal. Calcd. for $\mathrm{C}_{19} \mathrm{H}_{17} \mathrm{~N}_{3} \mathrm{O}_{5}$ : C, 62.12; $\mathrm{H}, 4.66 ; \mathrm{N}, 11.44$; found $\mathrm{C}, 61.83 ; \mathrm{H}, 4.71 ; \mathrm{N}$, 11.53 .

\section{(4-(3-(5-Bromobenzofuran-2-yl)ureido)benzoyl)glycine (11b)}

White powder m.p. $253-255{ }^{\circ} \mathrm{C}$; (yield 80\%), IR: 3425, 3323, 3218, 1721 and 1630; ${ }^{1} \mathrm{H}$ NMR $\delta$ ppm: 3.92 (d, 2H, J = 5.6 Hz, NH-C $\left.\underline{H}_{2}-\mathrm{COOH}\right), 6.51(\mathrm{~s}, 1 \mathrm{H}, \mathrm{Ar}-\mathrm{H}), 7.26(\mathrm{~d}, 1 \mathrm{H}, J=8.4 \mathrm{~Hz}, \mathrm{Ar}-$ H), $7.41(\mathrm{~d}, 1 \mathrm{H}, J=8.4 \mathrm{~Hz}, \operatorname{Ar}-\mathrm{H}), 7.58(\mathrm{~d}, 2 \mathrm{H}, J=8.4 \mathrm{~Hz}, \operatorname{Ar}-\mathrm{H}), 6.68(\mathrm{~s}, 1 \mathrm{H}, \mathrm{Ar}-\mathrm{H}), 7.84(\mathrm{~d}$,

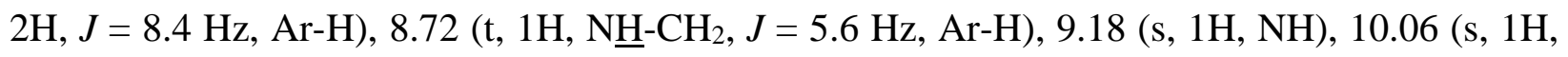
$\mathrm{NH}) ;{ }^{13} \mathrm{C}$ NMR $\delta$ ppm: $66.82,86.84,112.41,115.96,118.05,121.04,124.72,128.15,129.28$, 132.53, 142.26, 148.44, 150.69, 151.67, 166.40, 171.99; Anal. Calcd. for $\mathrm{C}_{18} \mathrm{H}_{14} \mathrm{BrN}_{3} \mathrm{O}_{5}: \mathrm{C}$, $50.02 ; \mathrm{H}, 3.26 ; \mathrm{N}, 9.72$; found $\mathrm{C}, 49.88 ; \mathrm{H}, 3.29 ; \mathrm{N}, 9.77$. 


\section{Carbonic anhydrase inhibition assay}

The carbonic anhydrase catalyzed $\mathrm{CO}_{2}$ hydration actions for the benzofuran-based carboxylic acid derivatives (9a-f and 11a,b) were assayed utilizing an instrument of Applied Photophysics stopped-flow [3], as described previously [4]. The enzymes are recombinant proteins prepared in our lab. Phenol red (at a concentration of $0.2 \mathrm{mM}$ ) has been used as indicator, working at the absorbance maximum of $557 \mathrm{~nm}$, with $20 \mathrm{mM}$ Hepes (pH 7.5) as buffer, and $20 \mathrm{mM} \mathrm{Na}_{2} \mathrm{SO}_{4}$ (for maintaining constant the ionic strength), following the initial rates of the $\mathrm{CA}$-catalyzed $\mathrm{CO}_{2}$ hydration reaction for a period of 10-100 s. The $\mathrm{CO}_{2}$ concentrations ranged from 1.7 to $17 \mathrm{mM}$ for the determination of the kinetic parameters and inhibition constants. For each inhibitor at least six traces of the initial 5-10\% of the reaction have been used for determining the initial velocity. The uncatalyzed rates were determined in the same manner and subtracted from the total observed rates. Stock solutions of inhibitor $(0.1 \mathrm{mM})$ were prepared in distilled-deionized water and dilutions up to $0.01 \mathrm{nM}$ were done thereafter with the assay buffer. Inhibitor and enzyme solutions were preincubated together for $15 \mathrm{~min}$ at room temperature prior to assay, in order to allow for the formation of the E-I complex. The inhibition constants were obtained by non-linear least-squares methods using PRISM 3 and the Cheng-Prusoff equation, and represent the mean from at least three different determinations. 


\section{Anti-proliferative activity against breast cancer cell lines}

Benzofuran-based carboxylic acid derivatives (9a-f and 11a,b) were screened for their potential antitumor potency against breast cancer cell lines; MCF-7 and MDA-MB-231. Both tested cell lines have been obtained from ATCC. The cells were maintained in Dulbecco's modified Eagle's medium (DMEM) supplemented with 10\% heat inactivated fetal calf serum (GIBCO), penicillin $(100 \mathrm{U} / \mathrm{ml})$ and streptomycin $(100 \mu \mathrm{g} / \mathrm{ml})$ at $37{ }^{\circ} \mathrm{C}$ in humidified atmosphere containing $5 \% \mathrm{CO}_{2}$. Cells at a concentration of $0.50 \times 10^{6}$ were grown in a $25 \mathrm{~cm}^{2}$ flask in $5 \mathrm{ml}$ of culture medium.

Assessment of cytotoxicity for the target carboxylic acids was carried out adopting SulfoRhodamine-B stain (SRB) assay [5], as described previously [6]. Briefly, Cells were inoculated

in 96-well microtiter plate $\left(5 \times 10^{4}\right.$ cells/ well) for $24 \mathrm{~h}$ before treatment with the tested compounds to allow attachment of cell to the wall of the plate. Tested compounds were dissolved in DMSO at $1 \mathrm{mg} / \mathrm{ml}$ immediately before use and diluted to the appropriate volume just before addition to the cell culture. Different concentrations of tested compounds, doxorubicin and sorafenib were added to the cells (three wells were prepared for each individual dose). Cells were incubated with the compounds for $48 \mathrm{~h}$ at $37^{\circ} \mathrm{C}$ and in atmosphere of $5 \% \mathrm{CO}_{2}$. After $48 \mathrm{~h}$ cells were fixed, washed, and stained for $30 \mathrm{~min}$ with $0.4 \%$ (w/v) SRB dissolved in $1 \%$ acetic acid. Unbound dye was removed by four washes with $1 \%$ acetic acid, and attached stain was recovered with Tris-EDTA buffer. Color intensity was measured in an ELISA reader. The relation between percent of surviving fraction and drug concentration is plotted to get the survival curve for each cell line. The concentration required for 50\% inhibition of cell viability $\left(\mathrm{IC}_{50}\right)$ was calculated and the results are given in Table 1. The results were compared to the effect of the reference drug doxorubicin. 


\section{Cell Cycle Analysis}

MDA-MB-231 cells were treated with benzofuran-based carboxylic acid derivative 9e for 24 $\mathrm{h}$ (at its $\mathrm{IC}_{50}$ concentration $\left.=2.52 \mu \mathrm{M}\right)$, and then cells were washed twice with ice-cold phosphate buffered saline (PBS). Subsequently, the treated cells were collected by centrifugation, fixed in ice-cold 70\% ( $v / v)$ ethanol, washed with PBS, re-suspended with 100 $\mu \mathrm{g} / \mathrm{mL}$ RNase, stained with $40 \mu \mathrm{g} / \mathrm{mL}$ PI, and analyzed by flow cytometry using FACS Calibur (Becton Dickinson, BD, Franklin Lakes, NJ, USA). The cell cycle distributions were calculated using CellQuest software 5.1 (Becton Dickinson).

\section{AnnexinV-FITC/PI Apoptosis Assay}

The phosphatidylserine externalization for breast MDA-MB-231 cancer cells after treatment by benzofuran-based carboxylic acid derivative $9 \mathrm{e}$ at its $\mathrm{IC}_{50}$ concentration, was assessed via Annexin V-FITC/PI dual staining assay utilizing Annexin AV/PI apoptosis detection kit (BD Biosciences) in accordance with manufacturer's protocol, as reported previously [7].

MDA-MB-231 cells were cultured to a monolayer then treated with 9e at its $\mathrm{IC}_{50}$ concentration. Cells were then harvested via trypsinization, and rinsed twice in PBS followed by binding buffer. Moreover, cells were re-suspended in $100 \mu \mathrm{L}$ of binding buffer with the addition of $1 \mu \mathrm{L}$ of FITC-Annexin $\mathrm{V}$ followed by an incubation period of $30 \mathrm{~min}$ at $4{ }^{\circ} \mathrm{C}$. Cells were then rinsed in binding buffer and resuspended in $150 \mu \mathrm{L}$ of binding buffer with the addition of $1 \mu \mathrm{L}$ of DAPI ( $1 \mu \mathrm{g} / \mu \mathrm{L}$ in PBS) (Invitrogen, Life Technologies). Cells were then analyzed using the flow cytometer BD FACS Canto II (BD Biosciences, USA) and the results were interpreted with FlowJo7.6.4 software. 


\section{References}

1. Ghabgharan, F.; Kooshkabadi, H.; Emami, M.; Rashidbaigi, A.; Shafiee, A. Synthesis and antibacterial and antifungal activities of alkyl and polyhalophenyl esters of benzo [b]-3-methyl2-furancarbamic acid. J. Pharm. Sci. 1976, 65, 1085-1087.

2. Hu, L.Y.; Boxer, P.A.; Kesten, S.R.; Lei, H.J.; Wustrow, D.J.; Moreland, D.W.; Zhang, L.; Ahn, K.; Ryder, T.R.; Liu, X.; Rubin, J.R. The design and synthesis of human branched-chain amino acid aminotransferase inhibitors for treatment of neurodegenerative diseases. Bioorg. Med. Chem. Lett. 2006, 16, 2337-2340.

3. Khalifah, R.G. The carbon dioxide hydration activity of carbonic anhydrase I. Stop-flow kinetic studies on the native human isoenzymes B and C. J. Biol. Chem. 1971, 246, 2561-2573.

4. Bua, S.; Lomelino, C.L.; Murray, A.B.; Osman, S.M.; Alothman, Z.A.; Bozdag, M., Aziz, H.A.A.; Eldehna, W.M.; McKenna, R.; Nocentini, A.; Supuran; C.T. "A Sweet Combination": Developing saccharin and acesulfame $\mathrm{K}$ structures for selectively targeting the tumor-associated carbonic anhydrases IX and XII. J. Med. Chem. 2020, 63, 321-333.

5. Skehan, P.; Storeng, R.; Scudiero, D. New colorimetric cyto-toxicity assay for anticancer-drug screening. J. Natl. Cancer Inst. 1990, 82, 1107-1112.

6. Eldehna, W. M.; El Kerdawy, A. M.; Al-Ansary, G. H.; Al-Rashood, S. T.; Ali, M. M.; Mahmoud, A. E. Type IIA-Type IIB protein tyrosine kinase inhibitors hybridization as an efficient approach for potent multikinase inhibitor development: Design, synthesis, antiproliferative activity, multikinase inhibitory activity and molecular modeling of novel indolinone-based ureides and amides. Eur. J. Med. Chem. 2019, 163, 37-53.

7. Sabt, A.; Abdelhafez, O.M.; El-Haggar, R.S.; Madkour, H.M.; Eldehna, W. M.; El-Khrisy, E.E.D.A.; Abdel-Rahman, M.A.; Rashed, L.A. Novel coumarin-6-sulfonamides as apoptotic anti-proliferative agents: synthesis, in vitro biological evaluation, and QSAR studies. J. Enzyme Inhib. Med. Chem. 2018, 33, 1095-1107. 


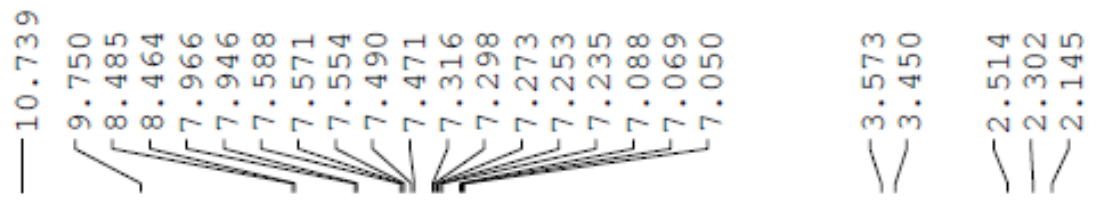

MBE . AO-1H-DMSO-29102019
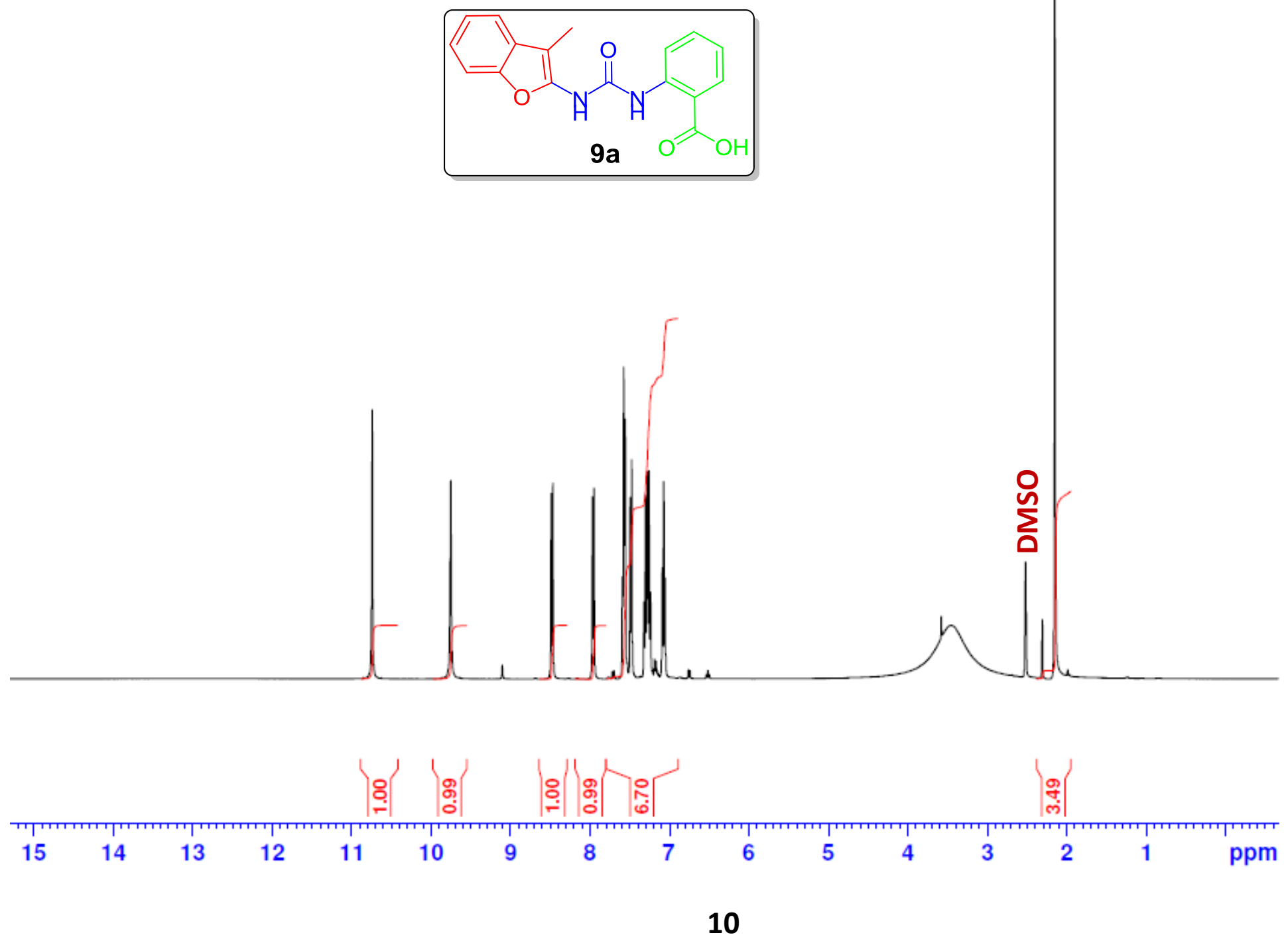

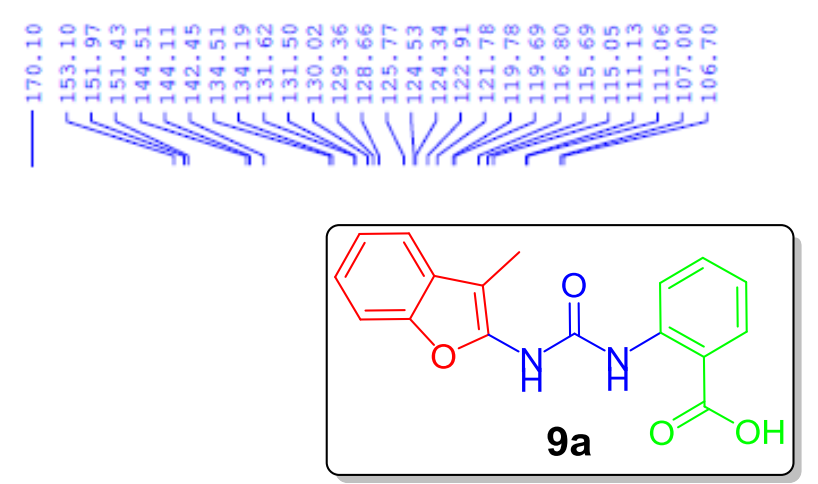

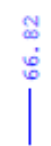

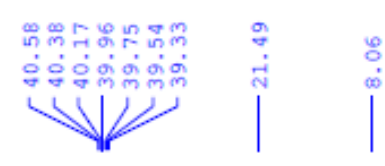

产

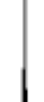

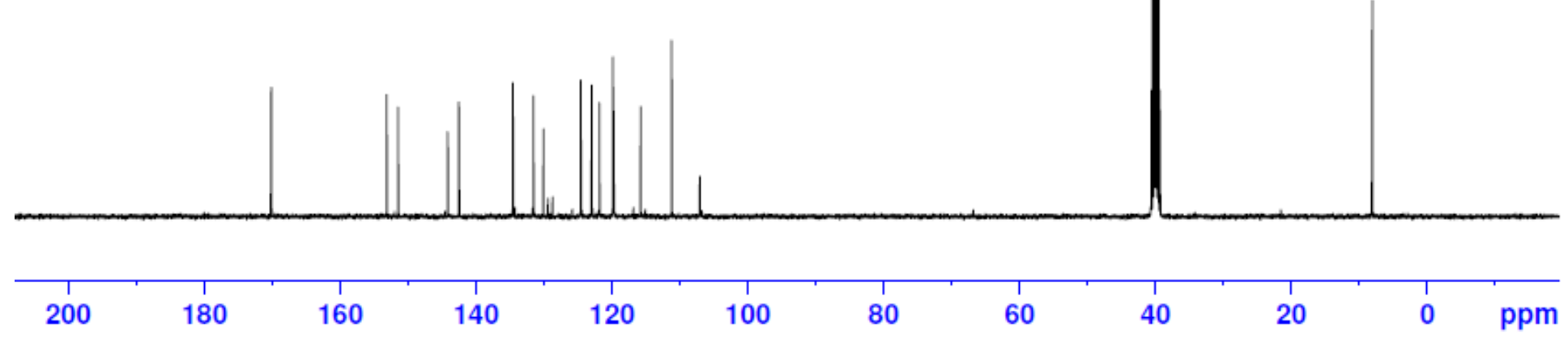

11 


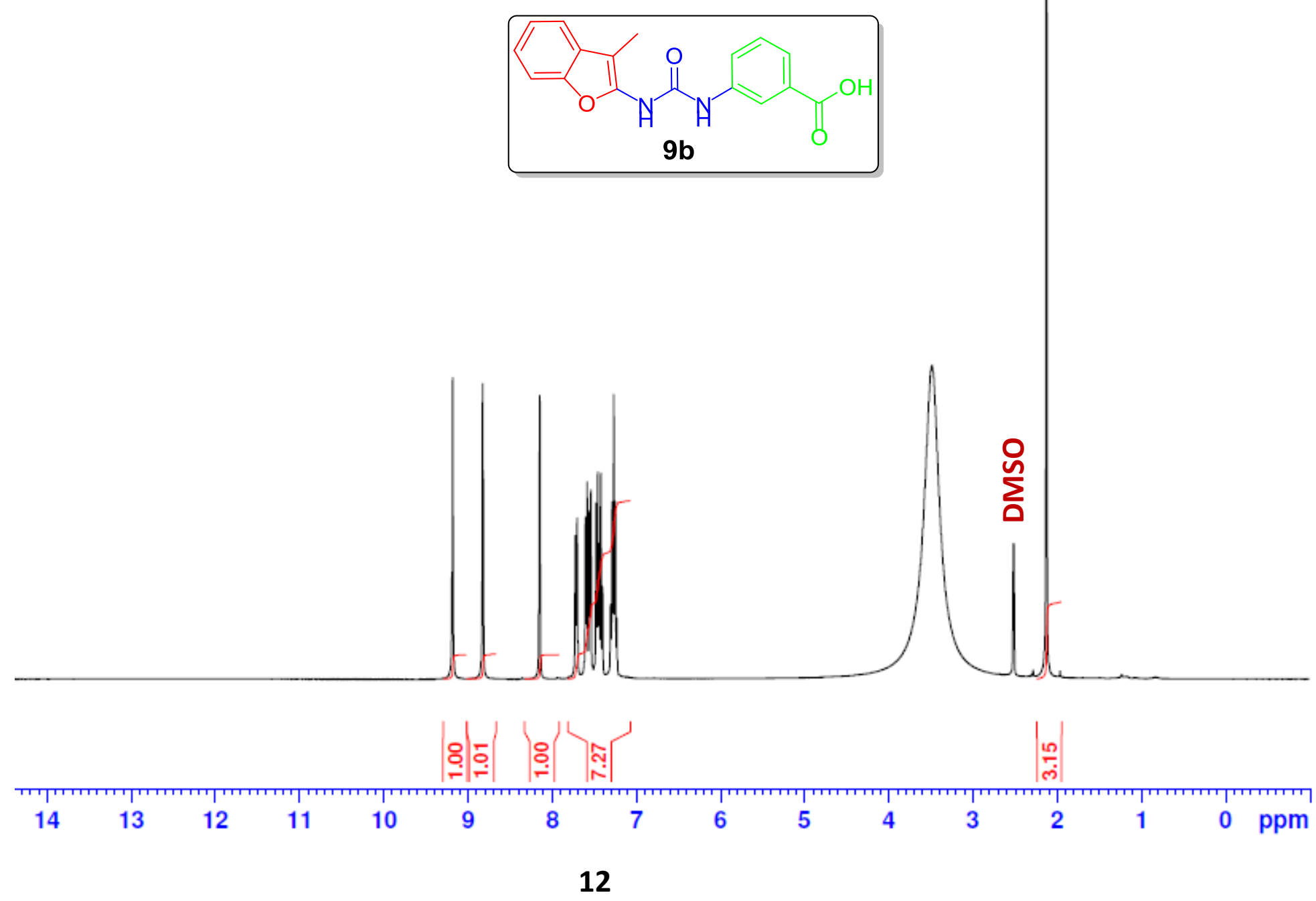

MBF .Am-1H-DMSO-29102019 

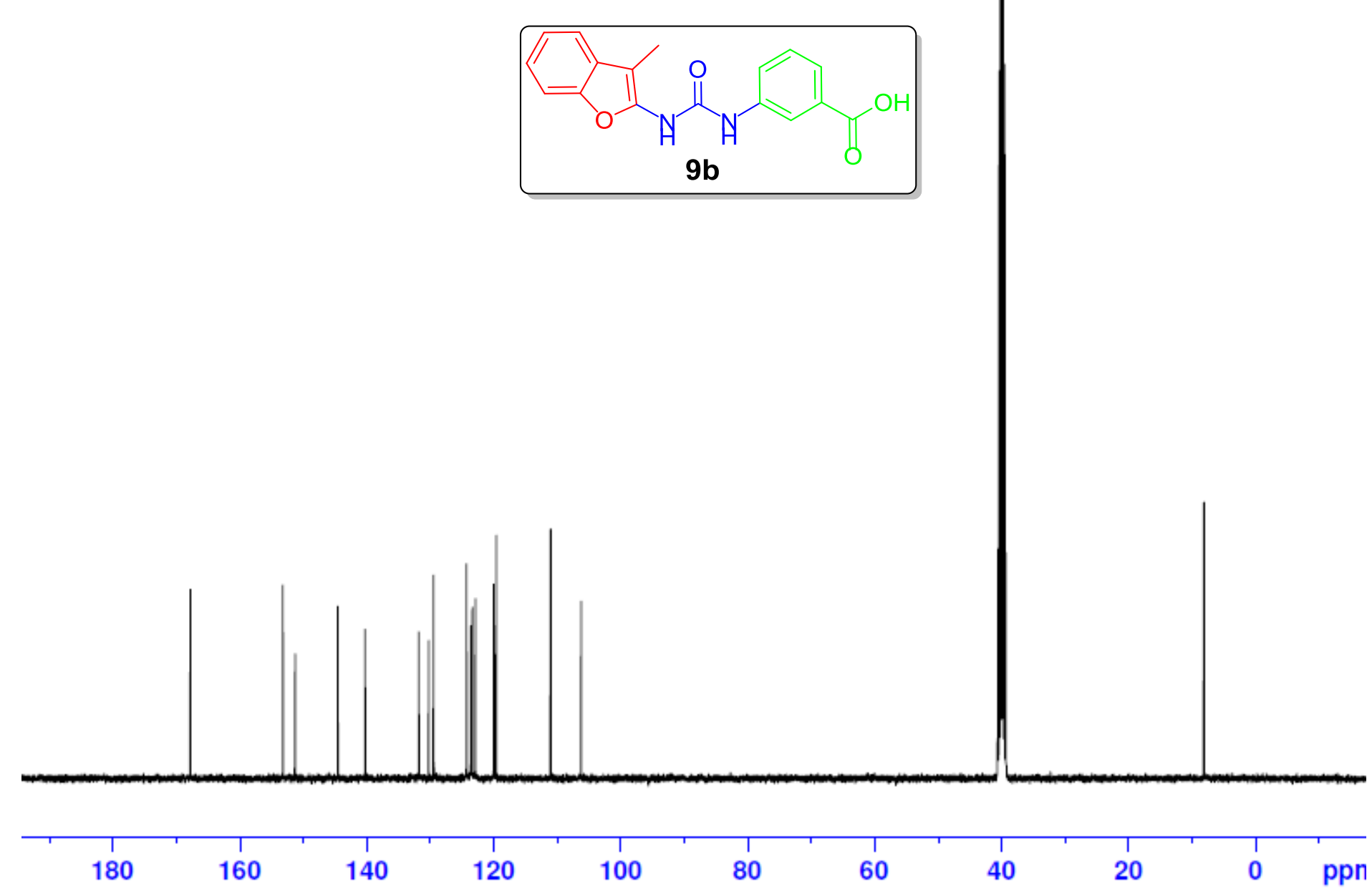
MBE .AP-1H-DMSO-29102019
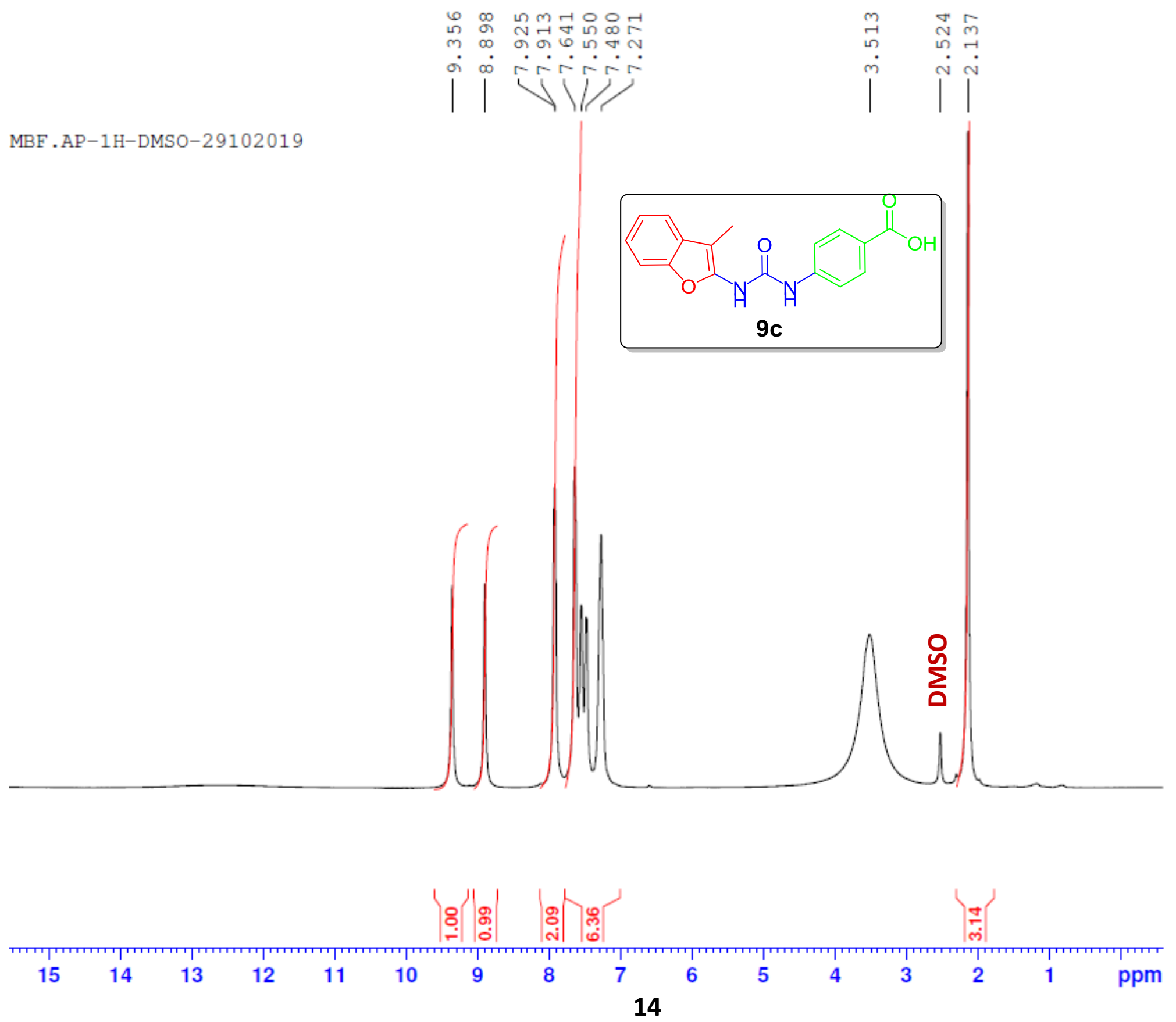

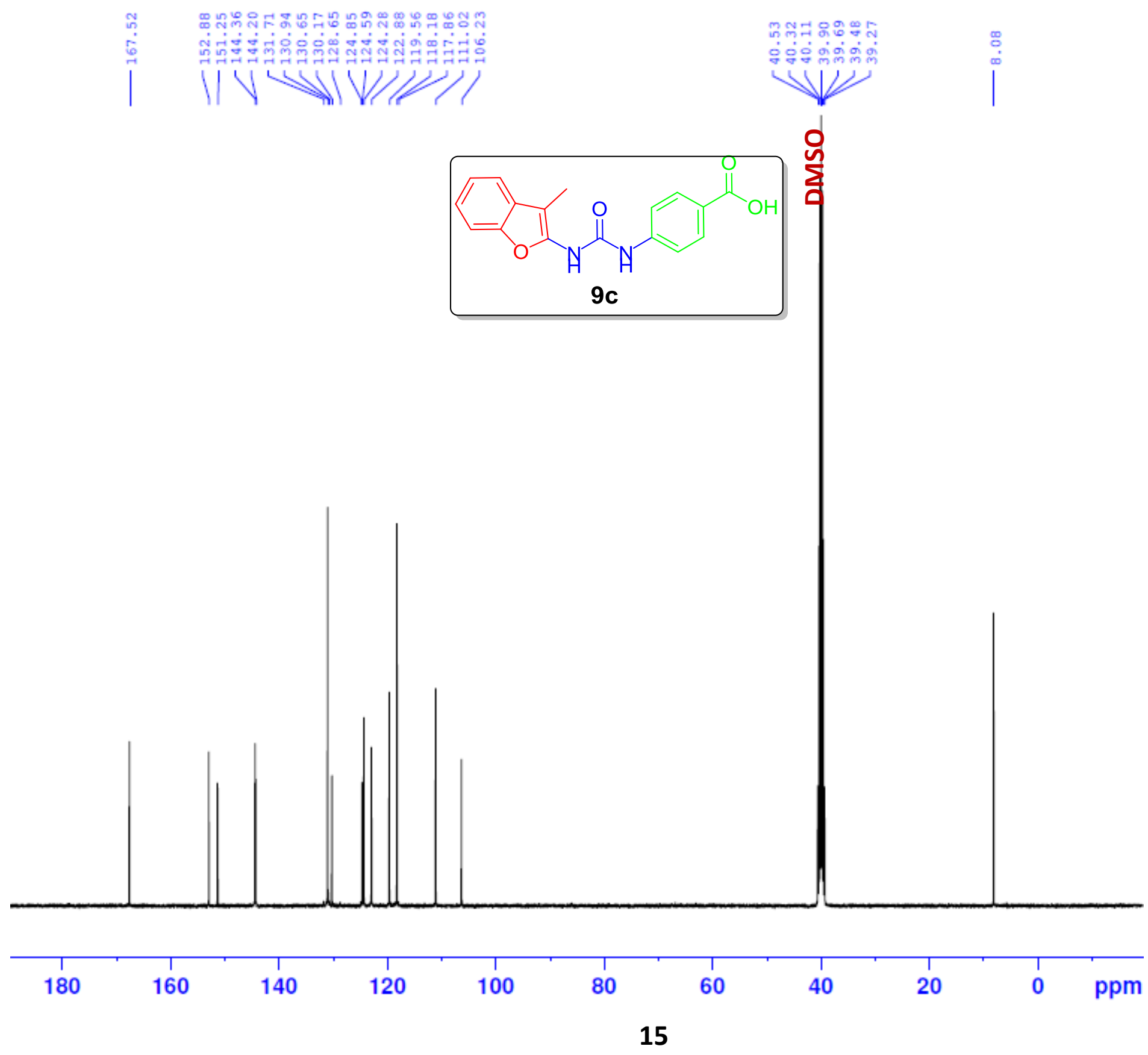

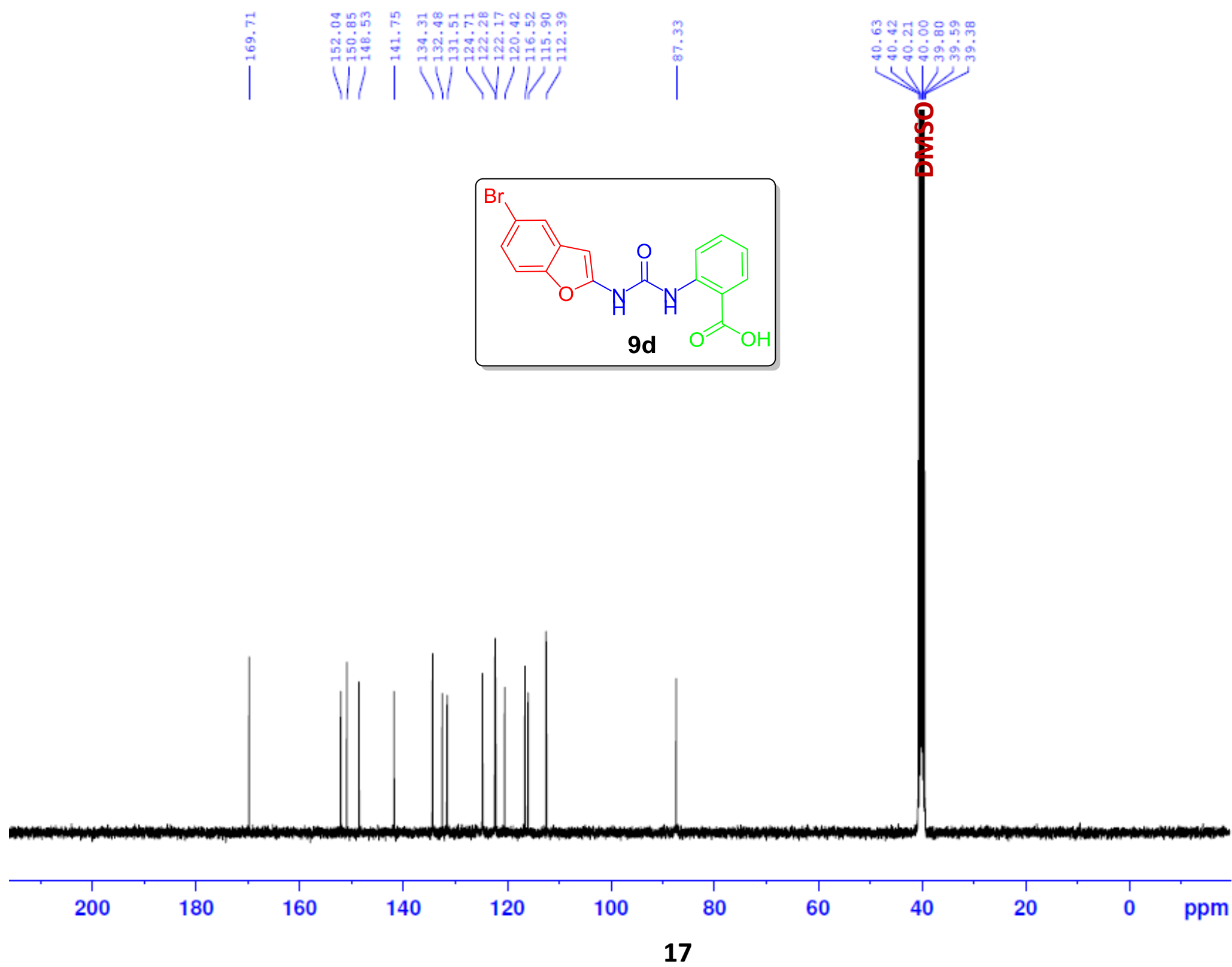


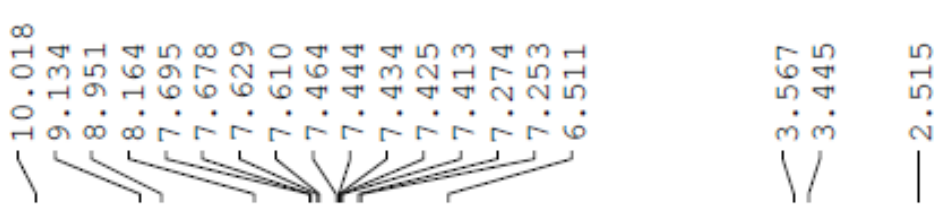

-1H-DMSO-13112019
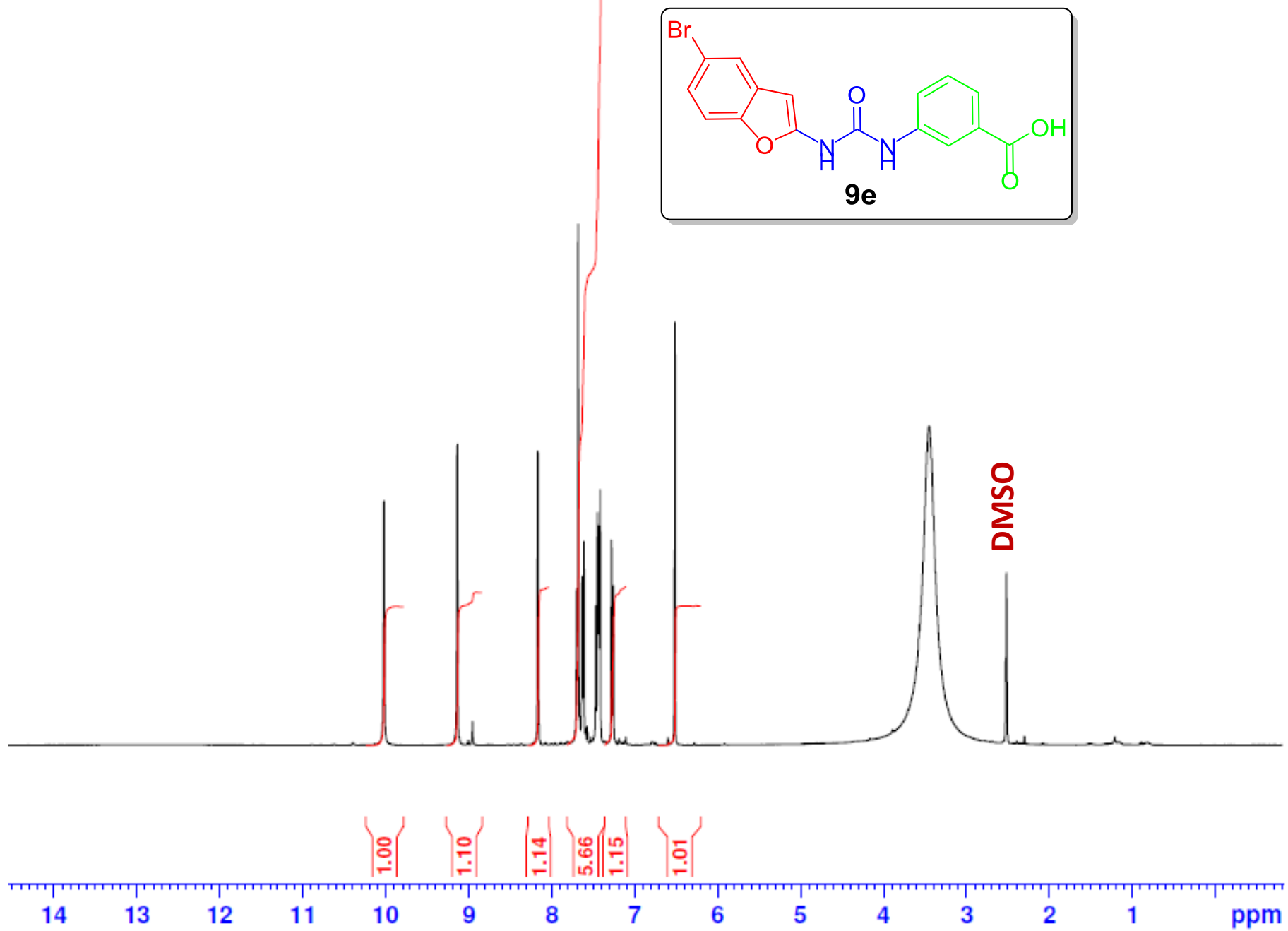

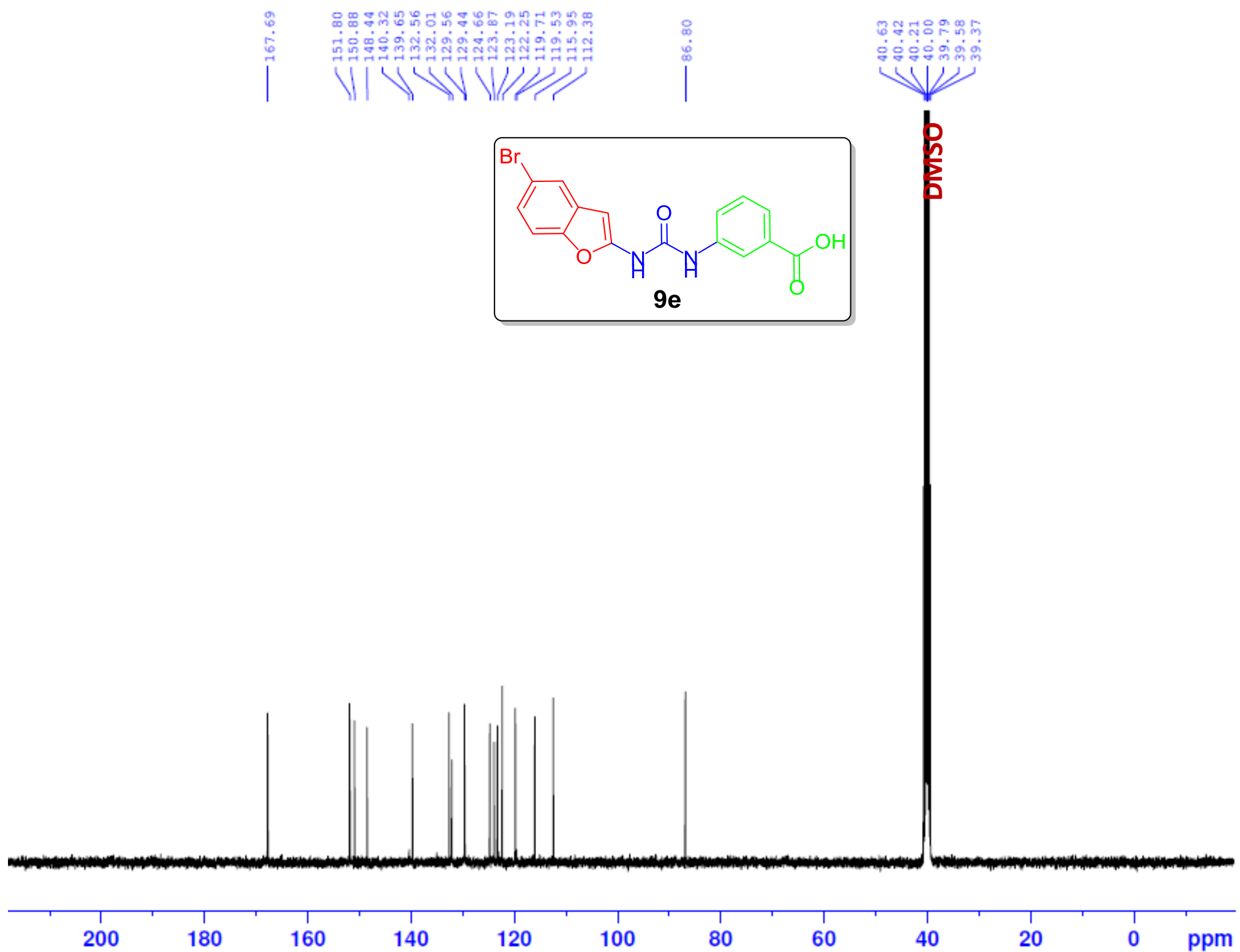
BBF-AP ) -1H-DMSO-13112019

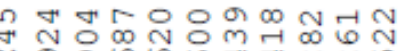

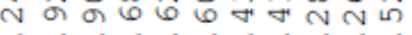

$\cos r i r a r$

$\leftrightarrow N$

ํㅏㄹ
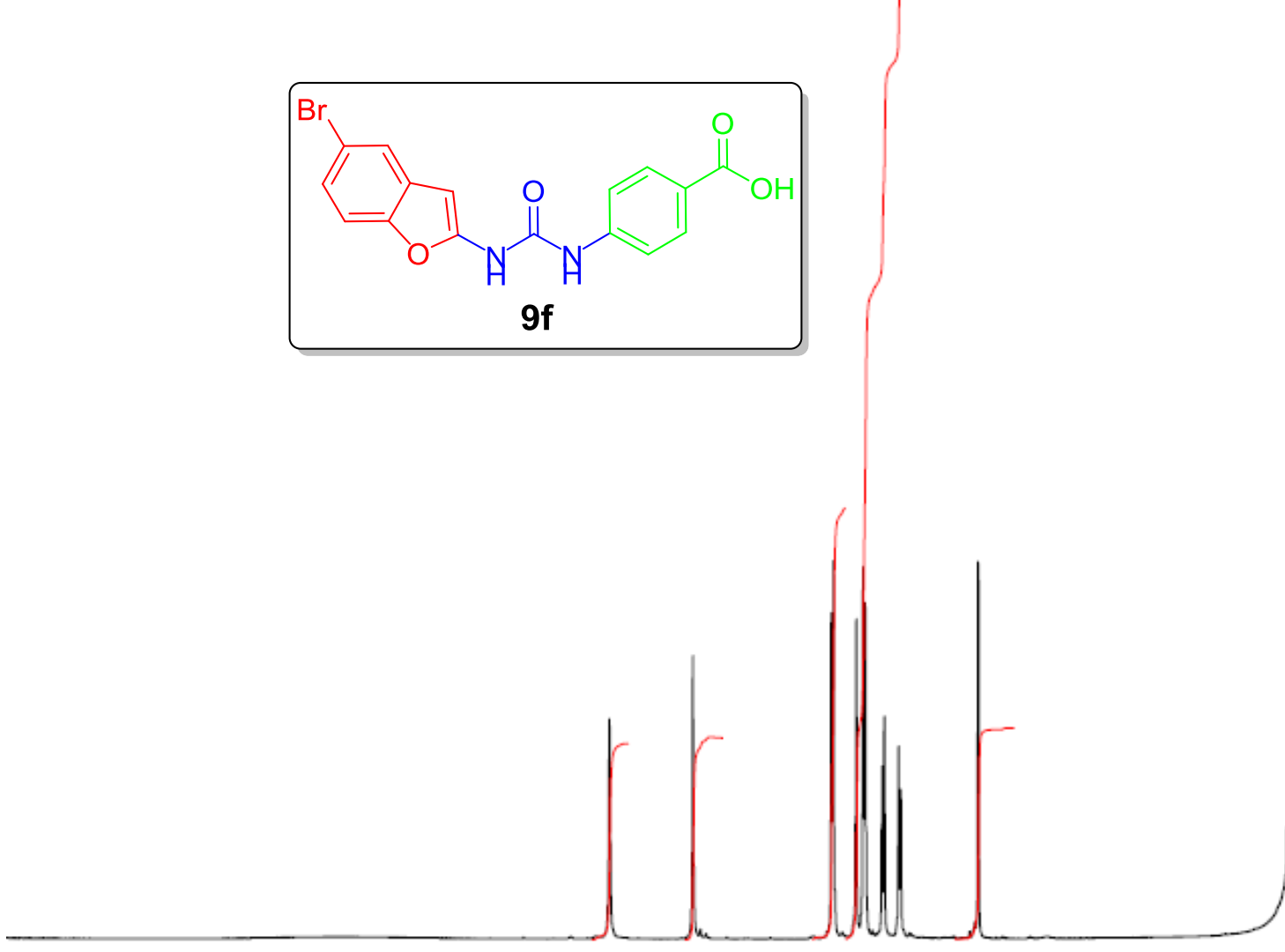

$\sum_{0}^{0}$

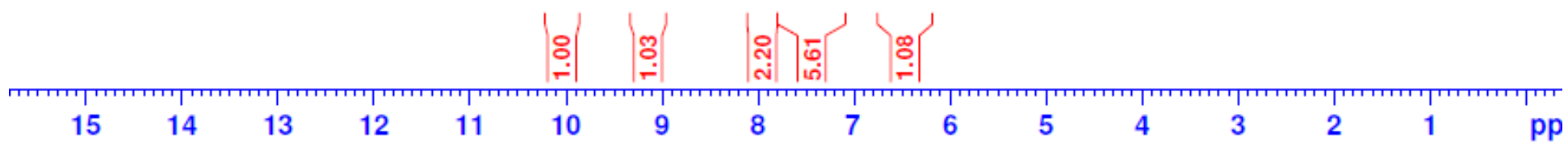



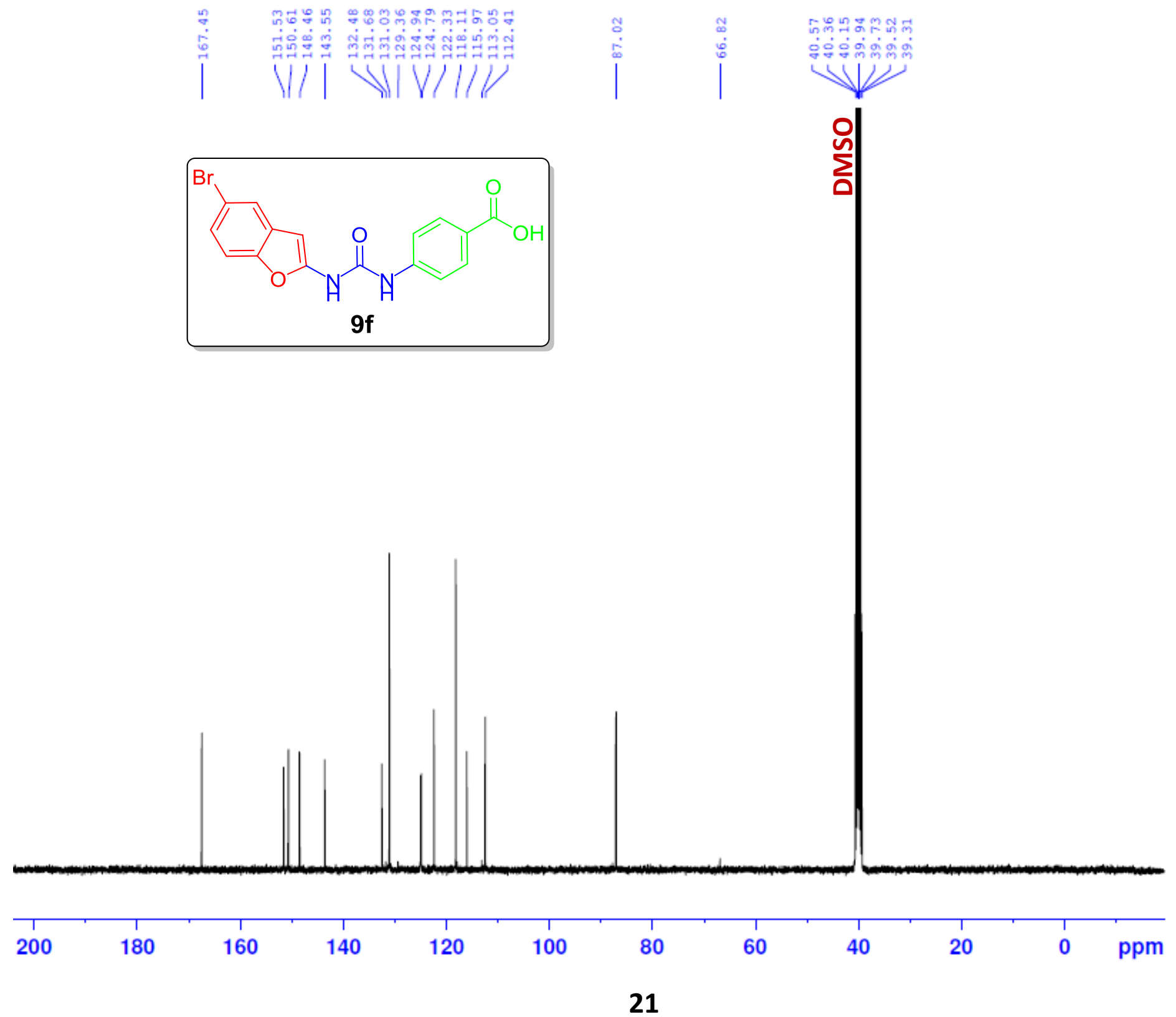

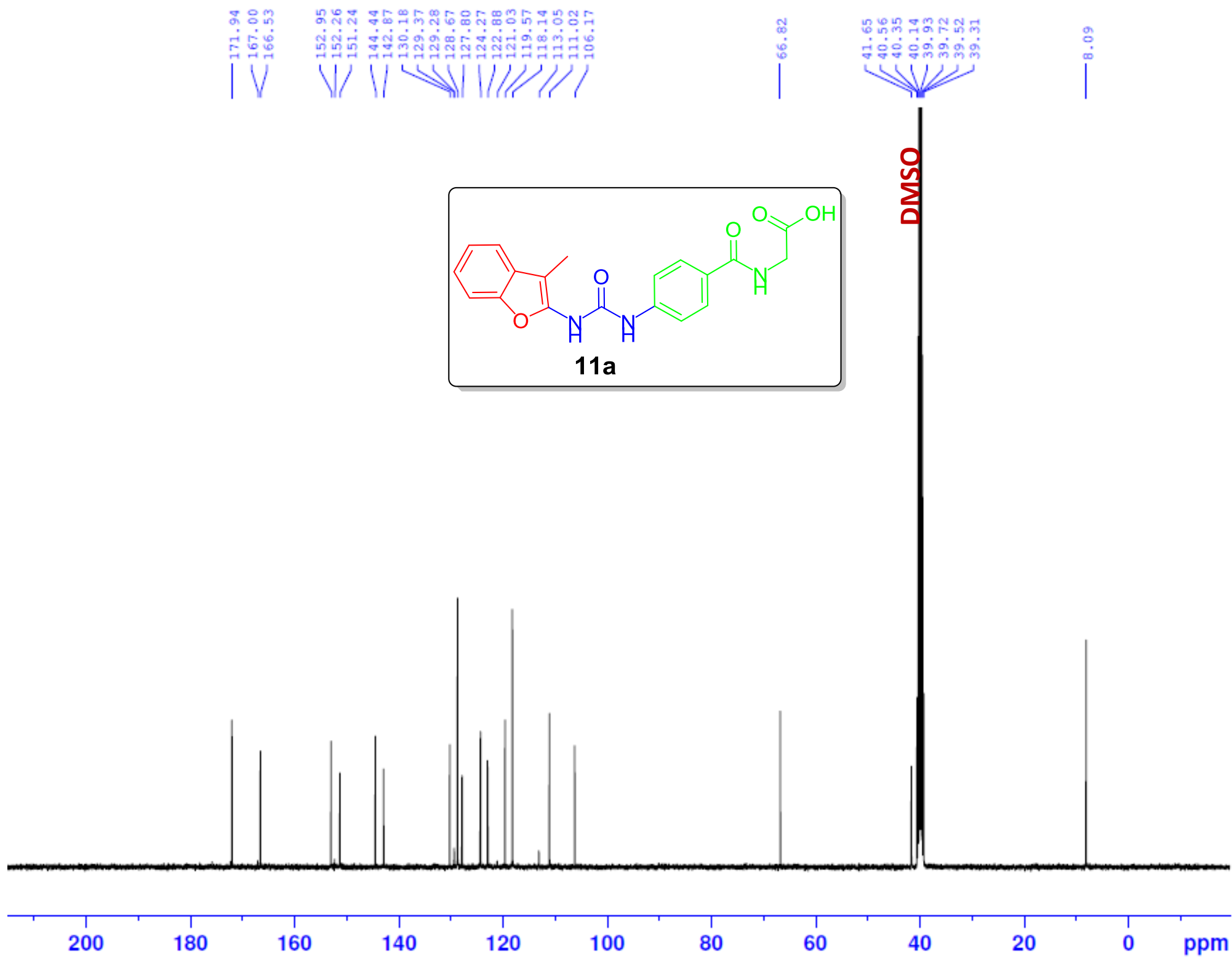

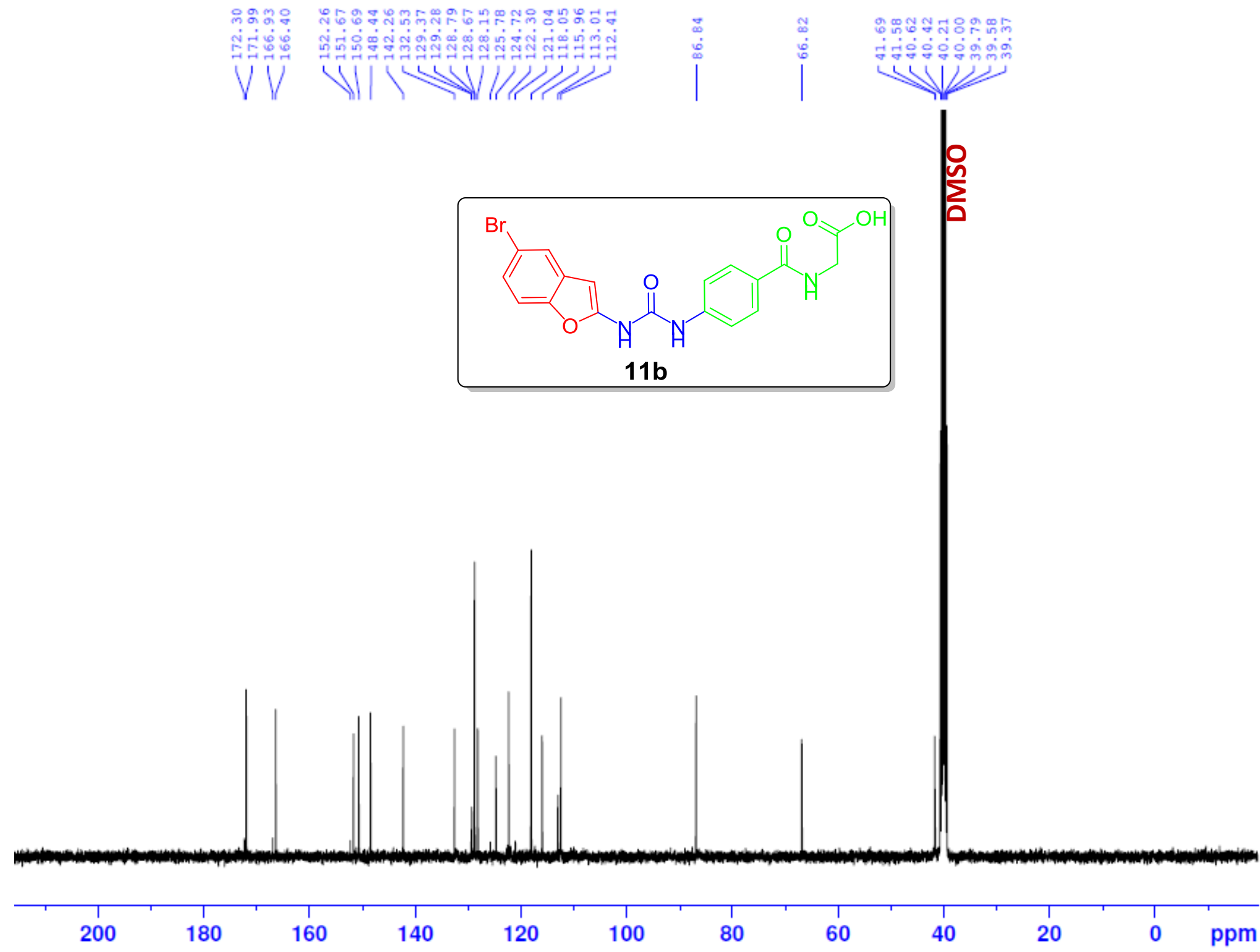

23 